\title{
Resistance to antimicrobial agents of Enterococcus spp. isolated at low and normal temperatures from water bodies of Vladivostok with anthropogenic load
}

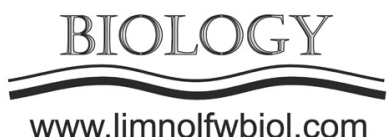

\author{
Uskova S.S., Martynova A.V.
}

Far Eastern Federal University, Department of Biodiversity and Marine Bioresources, Sukhanova Str., 8, Vladivostok, 690091, Russia

\begin{abstract}
This research was mainly aimed to study the antimicrobial sensitivity of the Enterococcus strains isolated at low and normal temperatures from anthropogenically loaded water of the Vtoraya Rechka River located in Vladivostok. The presence of enterococci in water can confirm anthropogenic pollution. For this reason, we conducted a study of antimicrobial agents resistance, which revealed that the bulk of the isolated strains was sensitive to tetracycline and vancomycin, intermediately sensitive to erythromycin and resistant to streptomycin.
\end{abstract}

Keywords: Enterococcus, antimicrobial resistance, tetracycline, streptomycin, erythromycin, rifampicin, vancomycin.

\section{Introduction}

The Enterococci are the conditionally pathogenic microorganisms, which are part of the normal human and animal microbiome. They have the natural resistance some antimicrobial agents and, getting into sewage waters, they can acquire an additional resistance to antimicrobial agents (Muto et al., 2003). Due to this fact, it is necessary to monitor the sensitivity of Enterococcus microorganisms to antimicrobial agents. For instance, a tetracycline possesses bacteriostatic activity, inhibits bacterial cell synthesis in ribosomes as well as binds metals ( $\mathrm{Ca}, \mathrm{Fe}, \mathrm{Mg}$, and $\mathrm{Mn}$ ), forming chelate complexes with them and inhibiting the enzyme systems (Egorov, 2004; Klez and Minakina, 2013). Such macrolide as erythromycin has bacteriostatic activity and suppresses protein synthesis of the microbial cell at the level of ribosomes, which is associated with the suppression of the peptidyl translocase enzyme. It is also important to study such substance as vancomycin, a glycopeptide with bactericidal effect destroying the synthesis of the cell wall (Egorov, 2004). Streptomycin refers to aminoglycosides that affect a bacterial cell, binding to the specific bacterial ribosome receptors, and inhibit protein synthesis. Rifampicin has a bactericidal effect and it suppresses RNA synthesis by complexing with DNA-dependent RNA polymerase (Egorov, 2004; Klez and Minakina, 2013).

\section{Materials and methods}

We studied 27 strains of Enterococcus isolated from the Vtoraya Rechka River at temperatures from $0{ }^{\circ} \mathrm{C}$ to $8{ }^{\circ} \mathrm{C}$ with a volume of $10 \mu \mathrm{l}$ and $20 \mu \mathrm{l}$. Antimicrobial resistance was studied by disc diffusion test (MUK 4.2.1890-04).

\section{Results}

Among 27 studied strains, $63 \%$ were sensitive to tetracycline, $6 \%$ had the intermediate sensibility to this drug, and $31 \%$ were resistant to this class of antimicrobials. $100 \%$ of the strains were resistant to streptomycin. Additionally, $60 \%$ of strains were intermediately sensitive to erythromycin, $40 \%$ were resistant to rifampicin, $27 \%$ had intermediate sensitivity, and $73 \%$ were resistant to rifampicin. Moreover, $87 \%$ were sensitive to vancomycin and $13 \%$ had intermediate sensitivity.

\section{Conclusions}

One of the main features of anthropogenic activity in the environment is the antimicrobial resistance in microbes isolated outside of a human microorganism. Furthermore, it can be a significant factor in the infection spread (McArthur and Tuctkfield, 2000). At the same time, this problem is also important for ecologists, because co-existence of allochthonous and autochthonous microorganisms may cause the horizontal spread of genes, e.g. of genes of antimicrobial resistance from autochthonous microbes to allochthonous ones and vice versa (Lobova et al., 2002).

*Corresponding author.

E-mail address: uskova.ss@yandex.ru (S.S. Uskova) 


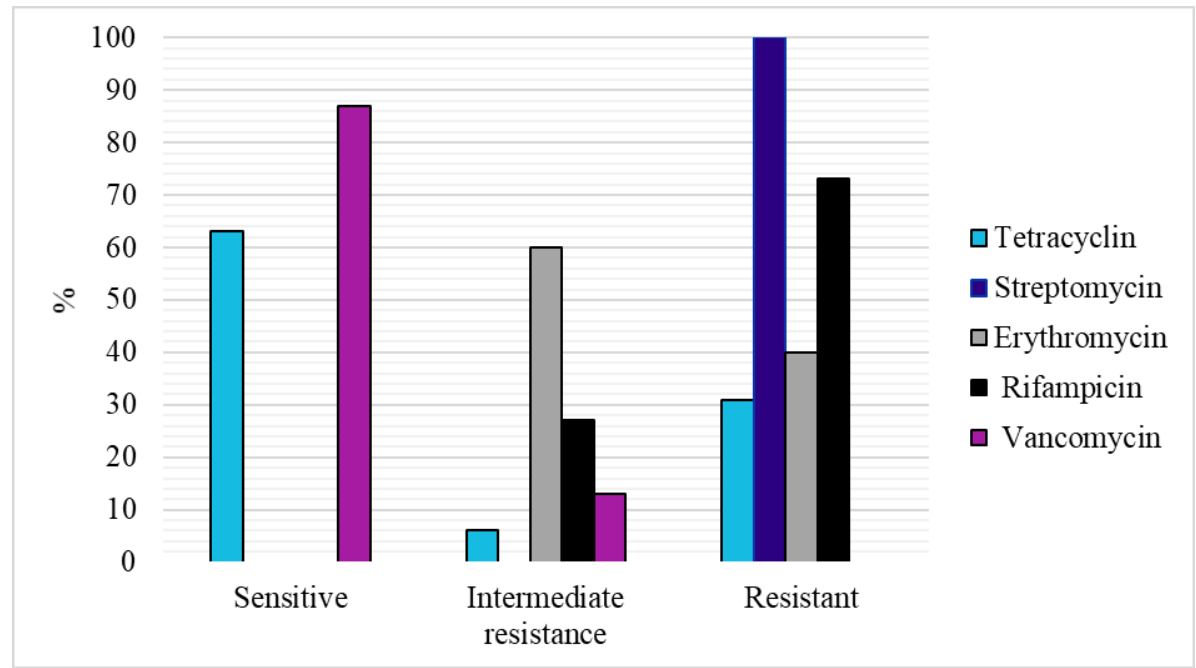

Fig.1. Antimicrobial resistance of Enterococcus strains (isolated from the Vtoraya Rechka).

There were studied the antimicrobial agents resistance of 27 strains of Enterococcus genera isolated in low and normal temperatures in a media with anthropogenic load. When analysing the gained data there was revealed that the most of the strains were sensitive to tetracycline and vancomycin, intermediately sensitive to erythromycin and $100 \%$ resistant to streptomycin.

\section{References}

Egorov N.S. 2004. Osnovy ucheniya ob antibiotikakh [Fundamentals of the doctrine of antibiotics]. Moscow: Nauka Publishing House of Moscow State University. (in Russian)

Klez O.P., Minakina L.N. 2013. Antibiotiki: uchebnoye posobiye dlya studentov vsekh fakultetov [Antibiotics: a textbook for students of all departments]. Irkutsk: SBEI HPE IGMU of the Ministry of Health of Russia. (in Russian)
Lobova T.I., Barkhatov Y.V., Popova L.Y. 2002. Antibiotic resistance of heterotrophic bacteria in Shira lake natural and anthropogenic impacts. Aquatic Microbial Ecology 30: 11-18. DOI: 10.3354/ame0300 114

McArthur J.V., Tuctkfield R.C. 2000. Spatial patterns in antibiotic resistance among stream bacteria: effects of industrial pollution. Applied and Environmental Microbiology. 66: 3722-3726. DOI: 10.1128/aem.66.9.3722-3726.2000

MUK 4.2.1890-04. 2004. Opredeleniye chuvstvitelnosti mikroorganizmov $\mathrm{k}$ antibakterialnym preparatam: Metodicheskiye ukazaniya [Determination of the sensitivity of microorganisms to antibacterial drugs: methodological guidelines]. Federal Center for State Sanitary and Epidemiological Supervision of the Ministry of Health of Russia. (in Russian)

Muto C.A., Jernigan J.A., Ostrowsky B.E. et al. 2003. SHEA Guideline for preventing nosocomial transmission of multidrug-resistant strains of Staphylococcus aureus and Enterococcus. Richet Infection Control and Hospital 24: 362-386. DOI: $10.1086 / 502213$ 